\title{
A pore-size classification for peat bogs derived from unsaturated hydraulic properties
}

\author{
Tobias Karl David Weber ${ }^{1, a}$, Sascha Christian Iden ${ }^{1}$, and Wolfgang Durner ${ }^{1}$ \\ ${ }^{1}$ Soil Science and Soil Physics Division, Institute of Geoecology, Technische Universität Braunschweig, Langer Kamp 19c, \\ 38106 Braunschweig, Germany \\ ${ }^{a}$ now at: Institute of Soil Science and Land Evaluation, University of Hohenheim, 70593 Stuttgart, Germany
}

Correspondence to: Tobias Karl David Weber (tobias.weber@uni-hohenheim.de.de)

Received: 19 May 2017 - Discussion started: 31 May 2017

Revised: 17 October 2017 - Accepted: 16 November 2017 - Published: 7 December 2017

\begin{abstract}
In ombrotrophic peatlands, the moisture content of the acrotelm (vadoze zone) controls oxygen diffusion rates, redox state, and the turnover of organic matter. Thus, variably saturated flow processes determine whether peatlands act as sinks or sources of atmospheric carbon, and modelling these processes is crucial to assess effects of changed environmental conditions on the future development of these ecosystems. We show that the Richards equation can be used to accurately describe the moisture dynamics under evaporative conditions in variably saturated peat soil, encompassing the transition from the topmost living moss layer to the decomposed peat as part of the vadose zone. Soil hydraulic properties (SHP) were identified by inverse simulation of evaporation experiments on samples from the entire acrotelm. To obtain consistent descriptions of the observations, the traditional van GenuchtenMualem model was extended to account for non-capillary water storage and flow. We found that the SHP of the uppermost moss layer reflect a pore-size distribution (PSD) that combines three distinct pore systems of the Sphagnum moss. For deeper samples, acrotelm pedogenesis changes the shape of the SHP due to the collapse of inter-plant pores and an infill with smaller particles. This leads to gradually more homogeneous and bi-modal PSDs with increasing depth, which in turn can serve as a proxy for increasing state of pedogenesis in peatlands. From this, we derive a nomenclature and size classification for the pore spaces of Sphagnum mosses and define inter-, intra-, and inner-plant pore spaces, with effective pore diameters of $>300,300-30$, and 30-10 $\mu \mathrm{m}$, respectively.
\end{abstract}

\section{Introduction}

Sphagnum moss is a dominant and keystone species in temperate and boreal peat bog development (Kuhry and Vitt, 1996). As an ecosystem engineer, Sphagnum moss (Jones et al., 1994) induces vertical growth of peat bogs and may lead to a manifestation of the ombrotrophication process (Balyea, 2009; Rydin and Jeglum, 2016), and has led to considerable terrestrial carbon accumulation during the Holocene (Frolking and Roulet, 2007). The ability of Sphagnum spp. to photosynthesize critically depends on the water regime and is limited to the topmost centimetres of the bog profile where growth occurs (Clymo, 1973). Under field conditions, soil hydraulic properties (SHP) control the water regime in the topmost, growing part of the peat profile and are thus a critical factor for moss growth and survival (Hájek and Beckett, 2008). The importance of capillary, film, and vapour flow processes for upward water fluxes in moss and peat has been emphasized by Hayward and Clymo (1982) and Price et al. (2009), while SHP accounting for these processes have only recently been identified by Weber et al. (2017a) for a limited number of samples.

In natural and undisturbed peat bog ecosystems there is a transition from living moss near the surface to heavily decomposed moss peat at greater depths (Clymo and Hayward, 1982; Limpens et al., 2008; Morris et al., 2011), with a concomitant change in SHP (e.g. Quinton et al., 2008; Price et al., 2008; McCarter and Price, 2012, 2014; Morris et al., 2015; Weber et al., 2017a). As Sphagnum decomposes, the fibrous material is biochemically broken up into smaller solid fragments (Rezanezhad et al., 2016). This change in physical structure reduces the pore sizes by a collapse of large pores 
and fine material filling the voids of the organic soil matrix. An increase in overburden leads to vertical shrinkage due to compression and a resulting increase in dry bulk density with depth (Clymo, 1978; Johnson et al., 1990; Price, 2003). The resulting strong decrease in saturated hydraulic conductivity, $K_{\mathrm{S}}\left(\mathrm{L} \mathrm{T}^{-1}\right)$ (Boelter, 1969; Ingram, 1978; Quinton et al., 2008), is positively correlated with the state of decomposition as shown by Ingram (1978), Clymo (1970, 1984), Clymo and Hayward (1982), Hayward and Clymo (1982), and Morris et al. (2015). Exceptions to this rule have been observed in cases where pipe flow (Holden, 2005), fire disturbances (Sherwood et al., 2013), and rapid climate change resulting in changes in vegetation and subsequent peat deposition history (Rydin and Jeglum; 2016; Hedwall et al., 2017) occur. In summary, the afore-mentioned processes constitute the entire continuous pedogenesis shaping the soil profile as an ongoing process (Blume et al., 2016). It should be noted that this includes the actively growing Sphagnum mosses, as Weber et al. (2017a) define the actively growing and living part of the Sphagnum mosses as part of the vadose zone, i.e. as part of the soil profile.

In soil hydrology, the Richards equation is widely used as a process model for simulating temporally and spatially variable water contents and fluxes in soils. Recently, Weber et al. (2017a) demonstrated that the Richards equation is an adequate process model for unsaturated water flow under evaporative conditions even for the uppermost layer of a bog, where the living Sphagnum moss can be treated as part of the soil. The solution of the Richards equation requires the parameterization of SHP. For systems with depth-dependent SHP like peat bogs, one can assume either a homogeneous system and identify effective SHP, or parameterize the SHP as depth-dependent functions (Durner et al., 2008; Vereecken et al., 2007). In peatland hydrology, the saturated hydraulic conductivity $K_{\mathrm{S}}$ is the most frequently measured hydraulic parameter for different depths. However, the saturated conductivity is not necessarily a good predictor for the unsaturated hydraulic conductivity curve, since the contribution of macro-porosity to preferential flow can be substantial in the saturated case. While the correlation of the saturated hydraulic properties, i.e. $K_{\mathrm{S}}$ and porosity, with depth has been well established, corresponding changes in the SHP, namely the water retention characteristic (WRC) and particularly the unsaturated hydraulic conductivity curve (HCC) with depth, have neither been extensively investigated nor been treated in numerical simulations.

In ecohydrological modelling of peatland mires containing Sphagnum, unimodal expressions of the WRC still dominate (e.g. Dimitrov et al., 2010; Sulman et al., 2012; Wu and Blodau, 2013; Mezbahuddin et al., 2016). However, the investigation of the WRC of organic soils has revealed bimodal pore-size distributions which have been found for different but limited pressure head ranges (Rezanezhad et al., 2009, 2010, 2016; Quinton et al., 2008, 2009; Kettridge and Bin- ley, 2011), and have so far rarely been expressed in terms of effective SHP over the full pressure head range.

Weber et al. (2017a) applied the highly sensitive method of inverse modelling evaporation experiments performed on Sphagnum moss and peat over a wide moisture range to parameterize SHP. The WRCs over the pressure head range from -1500 to $0 \mathrm{~cm}$ revealed a trimodal pore-size distribution (PSD) and clearly showed the necessity to account for adsorbed water in drying soil. Samples from two depths of the acrotelm were analysed and the identified SHP differed systematically and in a complex manner for the two depths. The HCC could not be described by simply scaling the saturated hydraulic conductivity, and showed the relevance of capillary and film components for water flow in organic soils. The trimodal nature of the PSD of the sample with living Sphagnum moss was linked to three conceptual pore spaces: pores between plant individuals (interplant pores), pores between branches and leaves of individual plants (intra-plant pores), and plant-internal water stored in hyaline cells (inner-plant pores). The deeper sample with decomposed moss showed a bimodal PSD with pores associated with the organic soil matrix and pores associated with the hyaline cells and its skeletal remnants (Fig. 1).

From this we state three hypotheses for this study. First, we expect a gradual shift in the characteristic pore sizes of the inter-plant and inner-plant pores with depth, due to increasing compaction and decomposition of the living moss material. Second, we expect a gradual disappearance of the distinct modalities (particularly the one that indicates the interplant pores) and an associated narrowing of the effective pore-size distribution with depth. Finally, we hypothesize that the variability of replicate samples from the same depth decreases with increasing depth, which is associated with the disappearance of the inter-plant pores. The last hypothesis is based on the assumption that samples become more homogeneous due to pedogenic processes such as biochemical degradation and compaction, and that the typical representative elementary volume for the different pore classes differs, being largest for the inter-plant pores.

Correspondingly, the research aims of this study are (i) to investigate in detail the gradual change in SHP with depth, encompassing the transition from living moss to peat, (ii) to analyse and quantify the spatial variability in SHP with depth, and (iii) to provide a unifying framework to distinguish between different pore systems in Sphagnum moss and peat which is based on the PSD and distinct pressure head ranges. To achieve these goals, a series of 28 laboratory evaporation experiments was conducted on undisturbed samples from the topmost $40 \mathrm{~cm}$ of a bog profile. The measured data were evaluated by inverse modelling using the Richards equation as a process model with the objective of identifying SHP for living moss and Sphagnum-derived peat. The results are presented in terms of average SHP for each depth, PSDs, and air-entry pressure heads of the individual pore systems. 


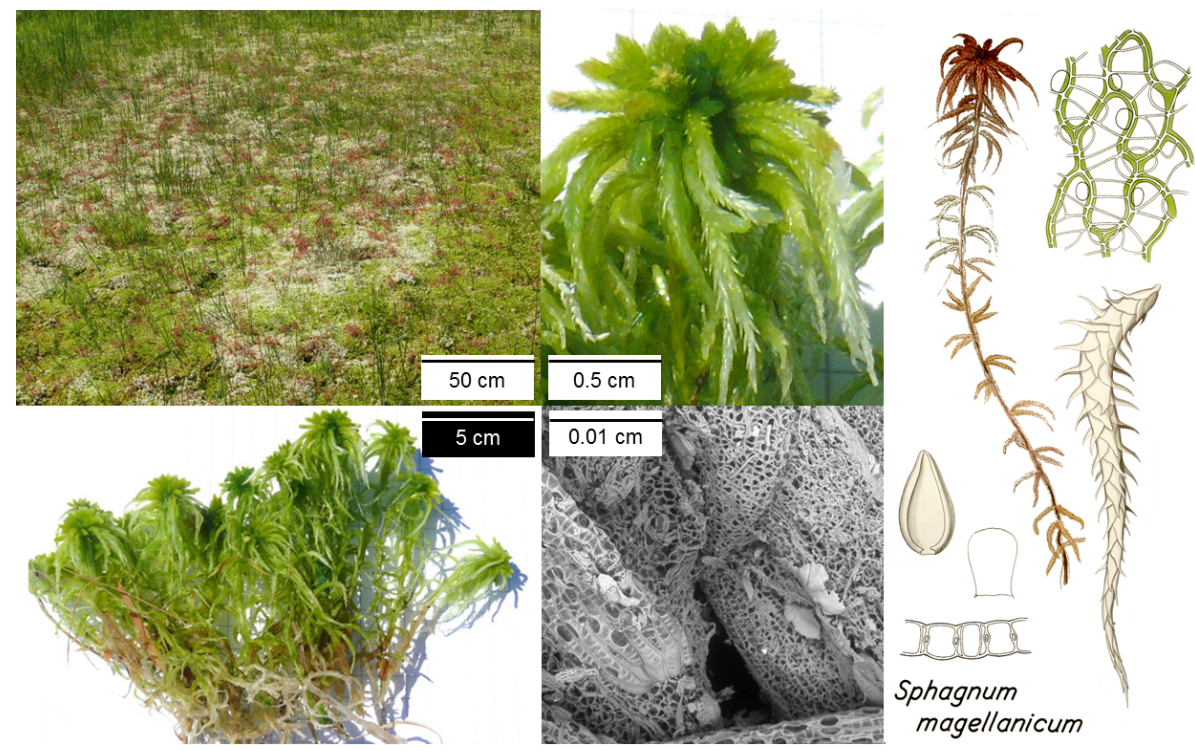

Figure 1. Sphagnum moss structures and soil pore sizes. (a) Sphagnum lawn with visible bleaching due to desiccation of the capitula (in the German language Sphagnum is also referred to as "Bleichmoos", which translates as "bleaching moss"), (a, b) images of Sphagnum cuspidatum H. Klinggr. to exemplify the (b) sampled and slightly spread out individuals with visible inter-connectedness of branches, (c) close-up of the capitulum with pending branches and leaves, and (d) scanning electroscope microscopy image of Sphagnum leaves on a branch with visible dark circles as the opening to the hyaline cells (courtesy of Reuven Simhayov). Right panel: drawing of Sphagnum magellanicum (courtesy of Bent Johnsen. ODepartment of Biology, University of Copenhagen) with (e) individual plant, (f) branch surface with skeletal structure in green, (g) branch with leaves, (h) cross section of a leaf with large hyaline cells, and (i) individual leaf.

\section{Materials and methods}

\subsection{Sampling site and sample preparation}

The samples were collected at an ombrotrophic peat bog, the Odersprungmoor, Harz Mountains, central Germany (UTM 32U $608000 \mathrm{mE} 5737000 \mathrm{mN} ; 800$ to $821 \mathrm{~m}$ a.s.l.). The Odersprungmoor formed on a saddle with an average downslope of $3 \%$ in the SE-NW direction. In the SW-NE direction it is located in a gentle trough position (Fig. 2; Jensen, 1990). The long-term average temperature is $6.8^{\circ} \mathrm{C}$ and annual precipitation is $1270 \mathrm{~mm}$ with a high inter-annual variance. The open bog is almost elliptical in shape and plan, with the longer axes oriented in the SE-NW direction, and has an area of 16.9 ha which is surrounded by spruce forest. The predominant bog vegetation consists of Sphagnum magellanicum Brid. and Sphagnum rubellum Wilson with interdispersed Eriophorum angustifolium Honck. Further extensive vegetation mapping was carried out by Baumann (2009). Figure 2 provides a detailed spatial reference and an overview of the peat types in the bog. The Odersprungmoor shows features of a poor fen in some small areas where it is slightly influenced by minerotrophic water, which only occurs on a small strip on the north-western flank (indicated by the arrows, Fig. 1, bottom panels). Most of the incoming water from the shallow soils formed on granite in the north-east is diverted past the bog along the northern rim of the bog towards the north-west (Border and Biester, 2015); thus, our sampling location is situated in the ombrotrophic part of the bog. Broder and Biester (2015) provided information on the geochemical composition of the substrate and pore waters which supports this. Weber et al. (2017b) give a detailed account of the carbon, water, and energy fluxes of the site during the vegetation period of 2013, a year with exceptionally dry summertime conditions in comparison to the 136-year long term record measured by the meteorological station of the German Weather Service (DWD) at nearby Braunlage.

In the acrotelm, a profile characterization with depth is possible as follows: the first $15 \mathrm{~cm}$ are composed of living moss, in $15-30 \mathrm{~cm}$ dead plant remnants dominate with some parts of the plants still visible, and the $30-40 \mathrm{~cm}$ samples contain the dark coloured decomposed moss peat. After the first $15 \mathrm{~cm}$ of living moss, a continuous increase in the state of decomposition is measurable (Broder and Biester, 2015). From the profile, 28 cylindrical samples of $250 \mathrm{~cm}^{3}$ volume and $5 \mathrm{~cm}$ height were obtained from frozen large sampling blocks using a drill rig (Quinton et al., 2009). We will refer to the samples by the respective mid sampling depths, i.e. $2.5(n=5), 7.5(n=6), 12.5(n=3), 17.5(n=3)$, $22.5(n=3), 32.5(n=4)$, and $37.5(n=4) \mathrm{cm}$ (number of replicates in brackets). Freezing is considered to be a negligible source of error (Branham and Strack, 2014). A comprehensive description of sampling protocol, sample treatment, and methodology is provided by Weber et al. (2017a). 

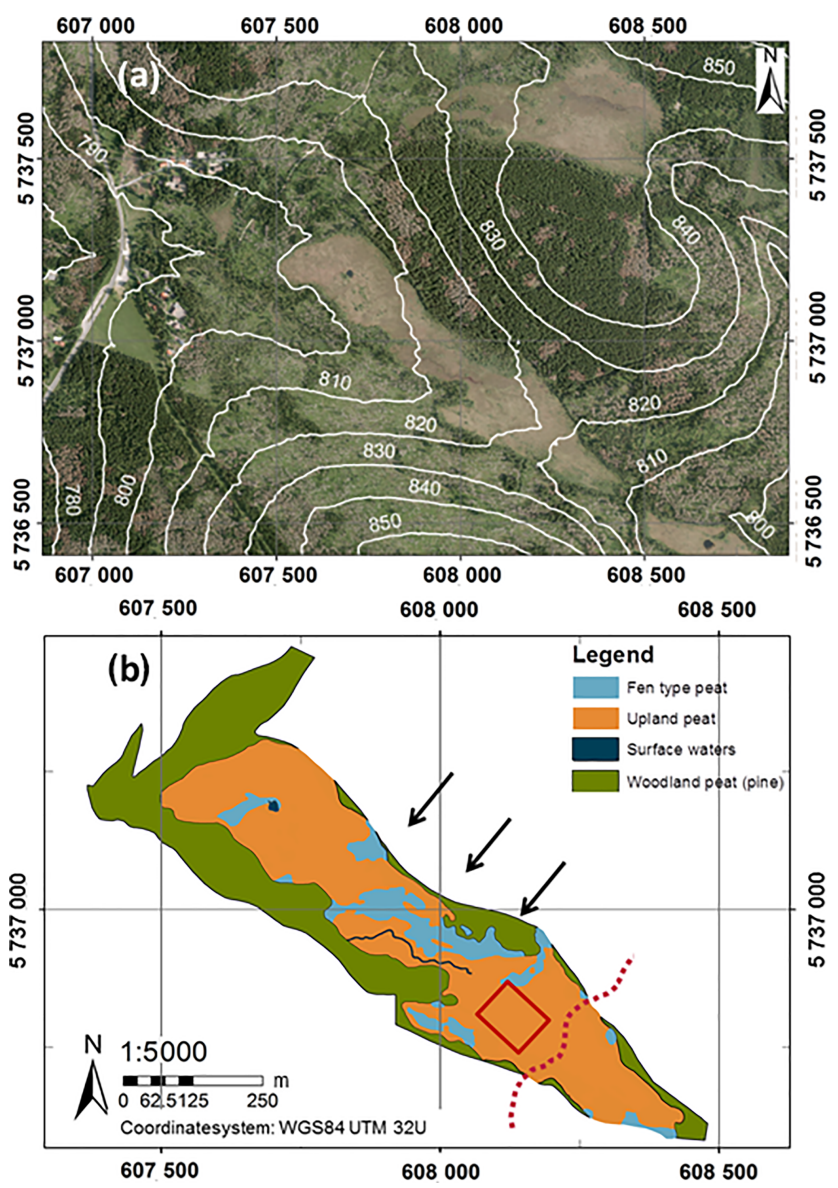

Figure 2. (a) Satellite image and elevation contours (m a.s.1.) of the Odersprungmoor; (b) vegetation mapping and characterization of the peatland. Black arrows indicate minerotrophic water influx into the peatland resulting in a higher proportion of fen type vegetation, the red dashed line is the approximate watershed divide, and the red box marks the sampling area.

\subsection{Identification of soil hydraulic properties}

Initially, the samples were saturated using de-aired and deionized water over a period of $48 \mathrm{~h}$. The saturated hydraulic conductivity $K_{\mathrm{S}}\left(\mathrm{cm} \mathrm{day}^{-1}\right)$ of all samples was determined by the falling head method (KSAT device version 1.4; UMS GmbH, Munich, Germany). Subsequently, transient evaporation experiments were carried out (Wendroth et al., 1993; Schwärzel et al., 2006) on samples $5 \mathrm{~cm}$ i.h. and $8 \mathrm{~cm}$ i.d., starting with fully saturated samples that were exposed to free evaporation in the lab. Matric potentials were measured at two depths, and water fluxes were derived from weight changes with time. The measured data were evaluated by inverse modelling using the Hydrus-1D code to solve the Richards equation numerically (Šimůnek et al., 2016). Model parameters were identified by minimizing a weighted leastsquares objective function (OF), which contained the time series of pressure heads at two depths $(1.25$ and $3.75 \mathrm{~cm})$ and the sample's average water content. Details are given by Weber et al. (2017a). Six different parameterizations of the SHP which can be categorized into two main groups were tested. The first model group is based on the widely used van Genuchten-Mualem model (van Genuchten, 1980), which conceptualizes all pore water to be contained and conducted in capillaries. We used unimodal (VGM1), bimodal (VGM2), and trimodal (VGM3) van Genuchten models to parameterize the SHP. The uni- and multi-modal van Genuchten models are used widely in soil hydrology and the equations are therefore not repeated here in detail, but can be found e.g. in Priesack and Durner (2006). The second model group consists of the Peters-Durner-Iden (PDI) model of the SHP. The model is physically more comprehensive in that it ensures zero water content at oven dryness, and accounts for water flow in completely filled capillaries, partly filled capillaries, adsorbed water films, and isothermal vapour diffusion. We used the parameterization derived by Peters (2013), in the modified form published by Iden and Durner (2014), and Peters (2014). The PDI retention curve model has an identical number of free parameters as the VGM. For the conductivity curve, two additional parameters are required which express (i) the relative contribution of a non-capillary conductivity to the total unsaturated conductivity, and (ii) the steepness of the decrease in the non-capillary conductivity curve with increasing suction. Similar to the VGM models, the PDI models were applied in uni-, bi- and tri-modal form (PDI equations are given in the Appendix).

The data from the evaporation experiments on the 28 samples were evaluated by inverse modelling using all six models of the SHP (VGM1, VGM2, VGM3, PDI1, PDI2, PDI3). In the parameter optimization, the saturated conductivity parameter, $K_{\mathrm{s}}$, was fixed to the measured value for each individual sample. This resulted in six sets of estimated model parameters, corresponding SHP, and model performance criteria per sample. Model selection was based on model ranking using the Akaike information criterion corrected for small sample size, AICc, as defined in Ye et al. (2008).

\subsection{Calculation of mean soil hydraulic properties}

After identifying the best parameterization of the SHP for each sample depth based on the AICc, the SHP of the replicates were averaged to obtain representative, mean SHP for each depth. Due to the non-linear dependence of the SHP on the model parameters, average SHP were not calculated by averaging parameters. The averaging was done by first generating 197 equidistant support points on the $\mathrm{pF}$ interval $[-3,6.8]$ (since the pressure head ranges across orders of magnitude in drying soil, we will use, for convenience, the $\mathrm{pF}$ unit in the remainder of this article. It is defined as the common logarithm of the negative pressure head $h(\mathrm{~cm})$, i.e. $\left.\mathrm{pF}=\log _{10}(-h)(-)\right)$. Subsequently, point values of the WRC and HCC were calculated at the support points for each replicate based on its respective best fitted model. The resulting 

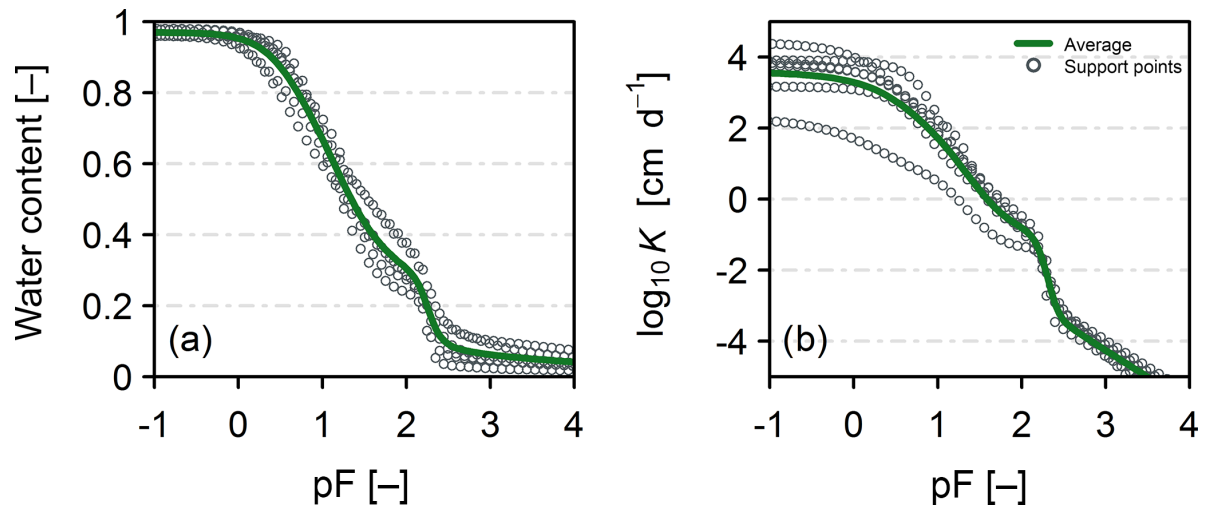

Figure 3. Example of the averaging process for (a) water retention curves and (b) hydraulic conductivity curves, shown for depth $7.5 \mathrm{~cm}$ (five replicates). Despite the variability of the individual curves, the key structural features are preserved.

datasets of the replicates were binned into one dataset and a new set of average PDI3 parameters was estimated by nonlinear least-squares fitting. Fitting was done sequentially: first the average WRC model parameters were estimated and, in a second step, the retention parameters were kept constant and the parameters of the HCC were estimated using $\log _{10}$ conductivity data in the objective function. The sequential parameter estimation circumvents the need to weight the data groups of $\theta(h)$ and $\log _{10} K(h)$, whereas if measured WRC and HCC data are used to estimate SHP model parameters simultaneously, it involves a weighted multi-objective problem. An example of the averaging method is illustrated in Fig. 3. The iterative least-squares minimization was done with the differential evolution algorithm (Price et al., 2006) as implemented in the DEoptim R package (Mullen et al., 2011).

\subsection{Pore-size distributions and classification of pore sizes}

According to the Young-Laplace equation (Jury and Horton, 2004), the pressure head at which a capillary tube drains is inversely proportional to the equivalent effective diameter, $d_{\text {eff }}(\mathrm{L})$, of that capillary which is calculated by

$d_{\mathrm{eff}}=\frac{4 \gamma \cos \beta}{|h| \rho_{\mathrm{w}} g}$

where $\gamma$ is the surface tension $\left(\mathrm{M} \mathrm{T}^{-2}\right)$ of water at $20^{\circ} \mathrm{C}, h$ is the pressure head $(\mathrm{L}), \rho_{\mathrm{w}}$ is the density of water $\left(\mathrm{ML}^{-3}\right)$, $g$ is the gravitational acceleration $\left(\mathrm{L} \mathrm{T}^{-2}\right)$, and $\beta(-)$ is the contact angle between water and the solids which we here set to $0^{\circ}$ (Valat et al., 1991), i.e. complete wettability is assumed during monotonic drying (Goetz and Price, 2015).

The PSD function, $f(h)$, was defined as the change in capillary saturation with $\log$ pressure head (Durner, 1994): $f(h)=-\frac{\mathrm{d} S_{\mathrm{c}}}{\mathrm{d}[\mathrm{pF}]}=-\log (10)|h| \frac{\mathrm{d} S_{\mathrm{c}}}{\mathrm{d} h}$,

where $S_{\mathrm{c}}$ is the capillary saturation function defined by Eqs. (A2) and (A3) in the Appendix. In multimodal pore systems, this can be applied to the capillary saturation functions of each pore system $S_{\mathrm{c}, i}(-)$, which define the individual pore systems that are superimposed in the effective PSD.

The analysis of the systematic changes in SHP with depth is based on Eqs. (1) and (2). We characterize the depth evolution of $d_{\mathrm{eff}}$ by the evolution of the median pore diameter, $d_{50}$, and the ratio of the 75 th to 25 th quantiles, $d_{75} / d_{25}$, of the pore-size distributions (Eq. 2). This is in analogy to characterizations of particle-size distributions.

A size classification of the individual pore domains was based on pressure heads at which air entry occurs into the different pore systems defining the multimodal PSD. In a first step, air-entry pressure heads, $h_{\mathrm{ae}, i}$, were determined for each superimposed effective PSD of each depth. From the seven determined values each for the first, second, and third PSDs of the depth-averaged SHP, as described in Sect. 2.3, a profile average for each modality was computed to determine the air entry.

In the case of the van Genuchten saturation model used in the PDI models, the air-entry pressure is usually approximated as the reciprocal of parameter $\alpha$ (Assouline et al., 1998). However, the steepness of the WRC is controlled by the shape parameter $n$, and only for relatively large values of $n$ is the air-entry pressure indeed approximately equal to $\alpha^{-1}$. Therefore, we define the air-entry pressure of a pore system as the pressure head where $S_{\mathrm{c}, i}=0.95$. For the weighted saturation function of the van Genuchten model, the equation to calculate the approximate air-entry value pressure of the $i$ th pore system is given by the equation

$h_{\mathrm{ae}, i}=\alpha_{i}^{-1} \cdot\left(0.95^{-1 / m_{i}}-1\right)^{1 / n_{i}}$.

This equation can equally be used for the PDI model. Equation (3) shows that the air-entry pressure depends on not only 
shape parameter $\alpha$, but additionally on parameter $n$, which characterizes the width of the PSD.

As mentioned above, three pressure heads are calculated delimiting the three pore domains, as averages over all depths.

\section{Results and discussion}

\subsection{Model performance}

The statistical metrics for all 168 inverse simulations (28 samples times 6 models) are listed in Table S1 in the Supplement, characterizing model performance by the AICc enabling model comparisons. The values for the best performing model for each sample are summarized in Table 1. According to the AICc, the PDI3 model performed best for 24 out of the 28 samples. For the remaining four samples, the VGM3 model performed best in three cases and the PDI2 in one. Thus, the PDI3 leads to the best model prediction in the majority of replicates regardless of sampling depths. We recall that this is achieved by estimating one additional conductivity curve parameter in the PDI compared to the VGM models with the same modality. This finding challenges the de facto standard usage of the VGM1 and VGM2 models for parameterizing the SHP of Sphagnum moss and peat and extends the theoretical considerations, results, and conclusions in Weber et al. (2017a) to multiple depths in the bog profile. It furthermore corroborates the fact that even model parameters of trimodal functions can be uniquely identified. Note that the use of an incorrect model, despite a lower number of parameters, often leads to very high parameter uncertainties like in Dettman and Bechtold (2016). As a consequence, the averaging of the SHP among the replicates was based on the PDI3 model for all depths.

\subsection{Soil hydraulic properties and pore-size distributions of all samples}

Figure 4 presents the WRCs (left panels), HCCs (middle panels), and PSDs (right panels) of all measured samples, grouped for the seven sampling depths (denoted A to G, from the top to bottom panels). A comparison of the SHP at the different depths reveals three main trends. First, the variability between the replicates decreases with increasing depth, i.e. the SHP of the replicates become more similar. Second, for all depths a comparable modality of relatively small pores is discernible, which starts to drain at about $\mathrm{pF}=2$ $(-100 \mathrm{~cm})$. Superimposed onto this pore system, there is a second and third modality indicating larger pore systems for the near-surface samples, with the third modality reflecting a pore domain close to water saturation. With increasing depth the variability in the two larger pore domains decreases considerably. Third, the HCCs for all depths appear very similar in the more unsaturated moisture range $(\mathrm{pF}>2)$, but diverge towards saturation. One possible reason for the scatter for $\mathrm{pF}<2$ is the insensitivity of evaporation experiments to changes in the $K(h)$ function in wet soil. This insensitivity occurs if the evaporation rate is of the order of $K(h)$ or smaller, leading to small gradients in pressure head which cannot be resolved by tensiometers (Peters and Durner, 2008). A more reliable determination of the HCC close to water saturation could be obtained by the tension disk method (Klute and Dirckson, 1986; McCarter et al., 2017), multi-step outflow (Durner and Iden, 2011), or multistep flux measurements (Weller et al., 2011). However, these methods have their own challenges when applied to organic soils, and the latter two have, to the best of our knowledge, not been applied to obtain SHP for organic media so far, although Qi et al. (2011) used multi-step outflow experiments to determine the WRC.

\subsection{Change in pore-system characteristics with depth}

To better identify the pore-system changes with depth, we compare mean SHP for all depths in Fig. 5. The trends with depth which have been observed for the individual samples now become much clearer. The seven mean WRCs (Fig. 5, left panel) show an increased water holding capacity with increasing depth across a wide pressure head range, from saturation up to $\mathrm{pF}=3.2$ (a pressure head of $-1500 \mathrm{~cm}$ ). This finding is supported by literature data for conditions near water saturation (Price et al., 2008; Price and Whittington, 2010; McCarter and Price, 2012; Goetz and Price; 2015). Concurrently, the HCCs show a pronounced decrease in the saturated conductivity and systematically higher unsaturated conductivities with increasing depth (Fig. 5, right panel), with a crossing point of the conductivity functions at around $\mathrm{pF}=1$.

From an ecophysiological point of view, it is interesting to analyse the relationship between SHP and the resilience against desiccation. In fact, all samples have a high water capacity around $\mathrm{pF}=2$. During meteorological conditions favouring prolonged periods of drying, the decrease in pressure head is slowed down by the release of this water, and low pressure heads leading to desiccation and cessation of photosynthesis (Hájek and Beckett, 2008) are reached only slowly. Commensurate with the WRC, the slope of the HCC around $\mathrm{pF}=2$ decreases as water drains from hyaline cells and their skeleton material, and hydraulic conductivity remains at values of approximately $10^{-2} \mathrm{~cm} \mathrm{day}^{-1}$ until approx. $\mathrm{pF}=2.5$, where it drops at all depths rapidly below $10^{-4} \mathrm{~cm}_{\text {day }}{ }^{-1}$. The relatively high hydraulic conductivity in the pressure head range until $\mathrm{pF}=2.5$ ensures an upward flow of water which contributes to the effective desiccation tolerance of the vegetation under field conditions.

We further observe that the WRCs shift with depth from a trimodal pore-size distribution to a bimodal one with a distinct expression of the two remaining pore systems. This is nicely recognizable from the plots of the PSDs in Fig. 6. To calculate meaningful pore-size parameters, we separated the 
Table 1. Statistical evaluation results of the inverse parameter estimation for 31 samples of eight mid sampling depths.

\begin{tabular}{|c|c|c|c|c|c|c|c|}
\hline $\begin{array}{l}\text { Sample } \\
\text { name }\end{array}$ & $\begin{array}{r}\text { Mid } \\
\text { sampling } \\
\text { depth } \\
(-)\end{array}$ & $\begin{array}{c}\text { OF } \\
\text { value }^{1} \\
(\mathrm{~cm})\end{array}$ & $\begin{array}{c}\operatorname{RMSE}_{\mathrm{W}}^{2} \\
0.75 \\
\left(\times 10^{4}\right)\end{array}$ & $\begin{array}{c}\mathrm{RMSE}_{\mathrm{W}}^{3} \\
0.25 \\
(\mathrm{~cm})\end{array}$ & $\begin{array}{c}\mathrm{AIC}_{\mathrm{c}}^{4} \\
(-) \\
(\mathrm{cm})\end{array}$ & $\begin{array}{r}\Delta \mathrm{AIC}_{\mathrm{c}}^{5} \\
(-)\end{array}$ & $\begin{array}{l}\text { Best } \\
\text { model }^{6} \\
(-)\end{array}$ \\
\hline A. 1 & 2.5 & 0.82 & 5.1 & 2.4 & 2348 & 417 & PDI3 \\
\hline A. 2 & 2.5 & 1.60 & 7.1 & 2.7 & 2734 & 795 & PDI3 \\
\hline A. 3 & 2.5 & 0.58 & 6.5 & 2.1 & 2688 & 394 & PDI3 \\
\hline A. 4 & 2.5 & 1.03 & 8.2 & 5.1 & 3518 & 321 & PDI3 \\
\hline A. 5 & 2.5 & 0.78 & 6.8 & 4.5 & 3051 & 432 & PDI3 \\
\hline B. 1 & 7.5 & 2.03 & 3.8 & 2.9 & 1766 & 806 & PDI3 \\
\hline B. 2 & 7.5 & 1.51 & 4.9 & 2.3 & 2156 & 954 & PDI3 \\
\hline B. 3 & 7.5 & 1.05 & 6.6 & 3.0 & 2600 & 413 & PDI3 \\
\hline B. 4 & 7.5 & 0.91 & 7.4 & 4.2 & 2595 & 782 & PDI3 \\
\hline B. 5 & 7.5 & 0.61 & 8.4 & 3.9 & 3692 & 350 & PDI3 \\
\hline B.6 & 7.5 & 1.41 & 4.3 & 3.7 & 3408 & 1566 & VGM3 \\
\hline C. 1 & 12.5 & 1.17 & 4.6 & 2.3 & 1856 & 642 & PDI3 \\
\hline C. 2 & 12.5 & 1.29 & 8.6 & 8.0 & 5562 & 27 & PDI2 \\
\hline C. 3 & 12.5 & 1.12 & 5.0 & 4.6 & 3594 & 797 & PDI3 \\
\hline D.1 & 17.5 & 0.95 & 2.6 & 4.9 & 2362 & 185 & PDI3 \\
\hline D. 2 & 17.5 & 2.31 & 3.5 & 3.8 & 3209 & 1727 & PDI3 \\
\hline D. 3 & 17.5 & 2.06 & 1.9 & 2.4 & 1727 & 2788 & PDI3 \\
\hline E.1 & 22.5 & 1.81 & 2.2 & 2.3 & 1724 & 1182 & PDI3 \\
\hline E. 2 & 22.5 & 2.45 & 4.1 & 2.1 & 2418 & 957 & PDI3 \\
\hline E. 3 & 22.5 & 3.99 & 2.6 & 3.7 & 2684 & 1654 & PDI3 \\
\hline F.1 & 32.5 & 3.69 & 3.0 & 2.9 & 1966 & 958 & VGM3 \\
\hline F. 2 & 32.5 & 2.52 & 2.1 & 3.9 & 2347 & 186 & PDI3 \\
\hline F.3 & 32.5 & 1.26 & 4.3 & 1.5 & 2102 & 447 & PDI3 \\
\hline F.4 & 32.5 & 0.95 & 4.8 & 3.5 & 2166 & 94 & VGM3 \\
\hline G.1 & 37.5 & 2.79 & 3.8 & 4.3 & 2640 & 653 & PDI3 \\
\hline G. 2 & 37.5 & 1.90 & 3.0 & 3.2 & 2162 & 470 & PDI3 \\
\hline G.3 & 37.5 & 0.54 & 2.6 & 2.7 & 1724 & 1424 & PDI3 \\
\hline G.4 & 37.5 & 0.38 & 4.6 & 2.1 & 2445 & 156 & PDI3 \\
\hline
\end{tabular}

fine pore system, characterized by the capillary saturation function with the parameters $w_{3}, a_{3}$, and $n_{3}$, from the system of larger pores, defined by the superposition of the two saturation functions with parameters $w_{2}, a_{2}$, and $n_{2}$, and $w_{1}$, $a_{1}$, and $n_{1}$, and calculated the median diameters of the two pore systems for each depth as the characteristic pore size. These characteristic pore sizes are indicated in Fig. 6 by the dashed vertical lines. From visual inspection, and confirmed by the values of the fitted parameters of the third pore subsystem (Table 2), it becomes obvious that the fine pore system remains virtually unchanged with depth, encompassing about 15 to $20 \%$ of the total pore space, $w_{3}\left(\theta_{\mathrm{s}}-\theta_{\mathrm{r}}\right)$. This pore system is characterized by a well-defined maximum of its pore-size distribution at $\mathrm{pF}=2.3$, which does not change with depth (Fig. 6). Also, the width of this fine pore system shows no change with depth. In contrast, the median equivalent diameter, $d_{50}(\mathrm{~L})$, from the superimposed first and second modalities drifts gradually from larger to finer pores (Fig. 6).

To further carve out the depth dependence of key characteristics of the pore systems, we show the depth dependence of saturated conductivity and two characteristic poresize parameters in Fig. 7. The near log-linear decrease in measured saturated hydraulic conductivity $K_{\mathrm{s}}$ (Fig. 7a) is in agreement with established trends in these ecosystems (Morris et al., 2015). The shift in the median pore size of the larger 
(a)

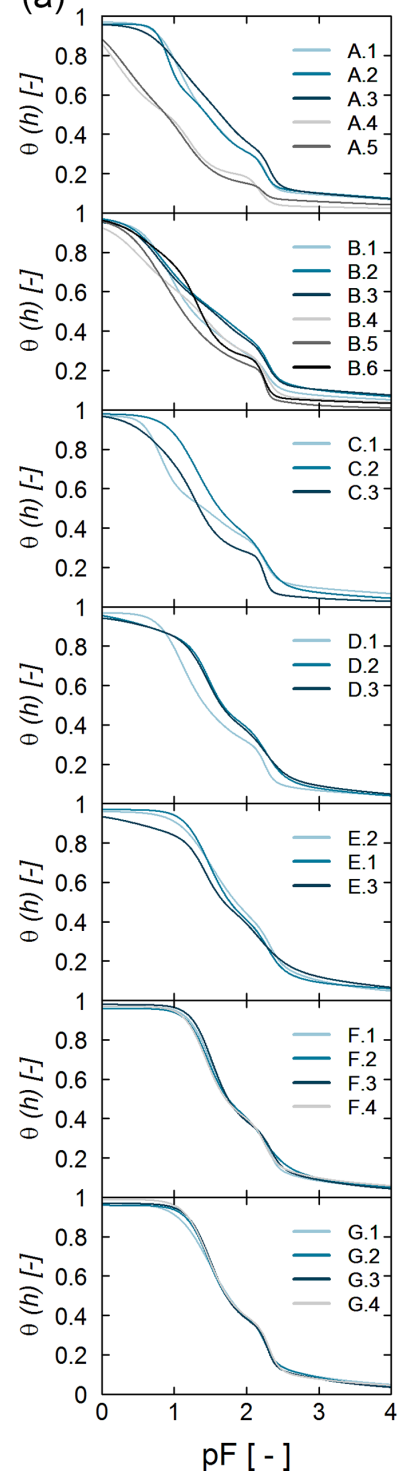

(b)

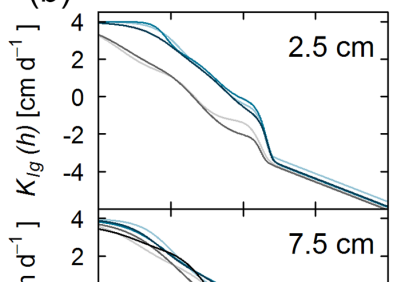

(c)

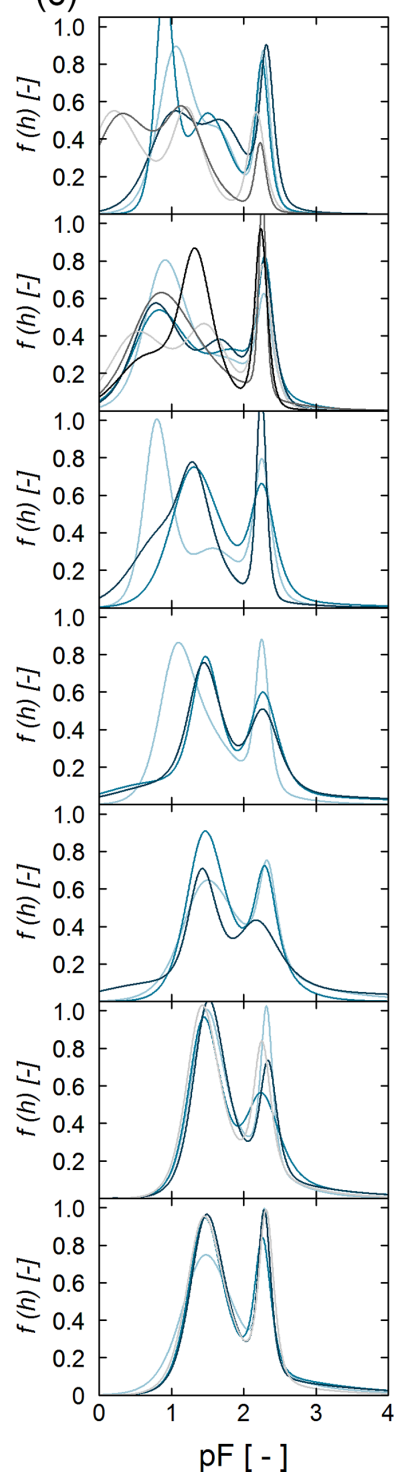

Figure 4. Left panels: water retention curves; centre panels: hydraulic conductivity curves; and right panels: pore-size distributions (of all 28 samples, $K_{\lg }$ refers to the common logarithm of the conductivity value).
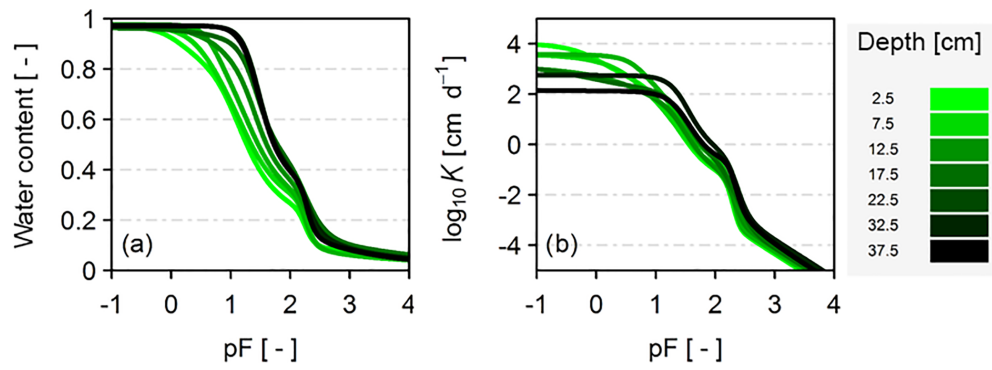

Figure 5. Mean (a) retention and (b) conductivity curves for the depths $2.5 \mathrm{~cm}$ to $37.5 \mathrm{~cm}$ in $5 \mathrm{~cm}$ increments. 


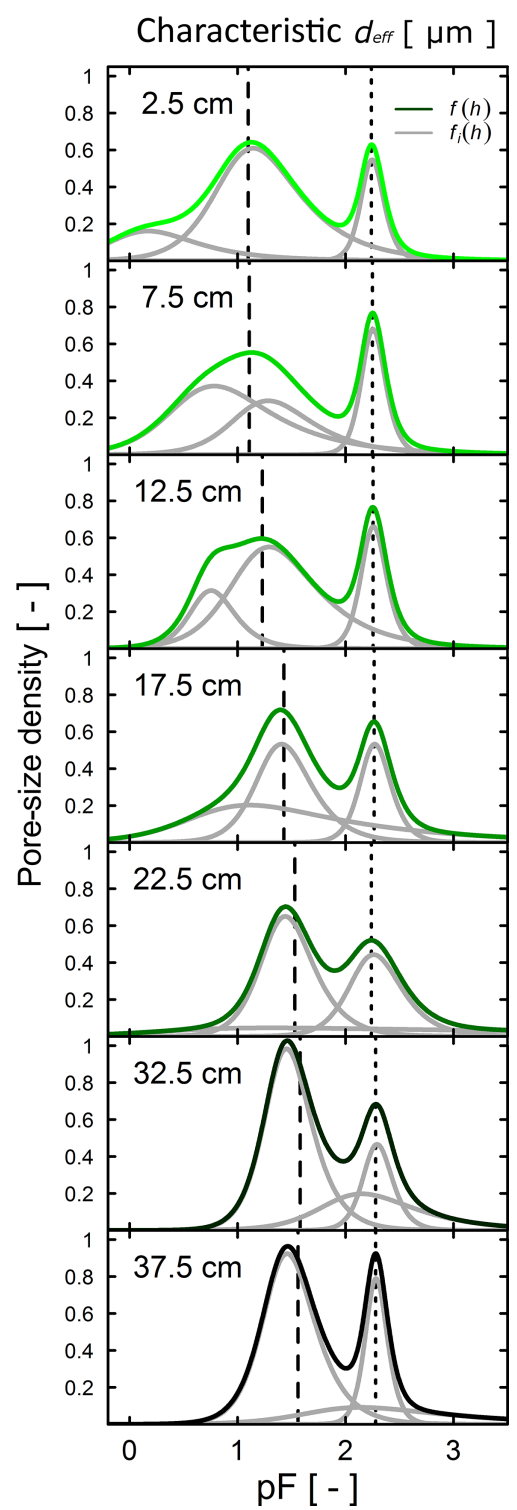

Figure 6. Continuous pore-size distributions calculated from Eq. (4) per depth showing the overlap of the three pore spaces. The dashed lines represent the median $\left(d_{50}\right)$ of the first and second pore domains, the increase of which positively correlates with increasing depth. The dotted lines mark the mode of the third modality which remains constant regardless of depth.

pore system indicates the strongest transition between 10 and $25 \mathrm{~cm}$ (Fig. 7b). The width of the associated pore system, expressed by the ratio of the first and third quartiles of the PSD, $d_{75} / d_{25}(-)$, shows a distinct and continuous narrowing with depth (Fig. 7c).

As a side note, we would like to comment on an interesting aspect of using the different parameterizations of the HCC. We found that the tortuosity-connectivity parameter $\tau$ in this study is positive for each individual sample parameterization with the PDI3 (Table S1). The same is true for the calcu- lated mean functions at all depths (Table 2). A positive value of $\tau$ is in agreement with its conceptual meaning (Mualem, 1976; Peters et al., 2011). This contrasts with reports from the literature (Price et al., 2008; Price and Whittington, 2010) and our findings with van Genuchten type functions, where $\tau$ is often negative (Table S1). Obviously, the use of a structurally more correct model of the SHP that accounts for partially filled capillaries prevents parameter $\tau$ from becoming negative. Conversely, if an inadequate model of the SHP is applied, $\tau$ has a tendency to become increasingly small and even negative because it induces the HCC to be less steep in the medium to dry range. Although this effect may be welcome to describe measurements, it is obtained by a physically implausible value of the shape parameter (Hoffman-Riem et al., 1999). Another important feature of the identified values of $\tau$ is their relatively small variation with depth.

The gradual change in PSDs with depth summarized by Fig. 6 can be explained by the origin of the samples and the pedogenic processes they have undergone, i.e. biochemical degradation breaking up fibres into smaller pieces (e.g. Rezanezhad et al., 2016), compaction (Price and Schlotzhauer, 1999), the shrinkage and swelling of bog soils (Schlotzhauer and Price, 1999; Price et al., 2003; Price, 2003; Glaser et al., 2004), and freeze-thaw processes (Meiers et al., 2013). These findings are corroborated by a positive relationship between depth and advance in decomposition at this site (Broder and Biester, 2015). Obviously, these processes lead to a homogenization of the organic material, a disappearance of the largest pores, and thus to a smaller spatial variability of the SHP at greater depths. While in the upper $15 \mathrm{~cm}$ the living moss reveals a large natural phenotypic variability over orders of centimetres, the dead plant remnants at 15$30 \mathrm{~cm}$ have already been subject to some compaction and the inter-plant pores are filled with smaller particles. The most decomposed samples from 30 to $40 \mathrm{~cm}$, which lie beneath the water table most of the time, are the most homogeneous and have completely lost the distinct trimodality in the PSD, which was evident for the samples from near the surface. The deepest samples are also the most homogeneous in colour and solid particle size. It is worthwhile noting that the PSDs are basically bimodal, but this does not contradict the superiority of using a trimodal parameterization (see Sect. 3.1 and Table 1) as indicated by the AICc. The superposition of PSDs can improve the overall description, even if they do not represent two distinct pore systems with different characteristic pore sizes. This was also discussed for the bimodal van Genuchten model by Zurmühl and Durner (1998) and for organic soils by Weber et al. (2017a). Without contradiction of the presented model, we point out that preferential flow may be an important driver for saturated flow on the very large scale. 

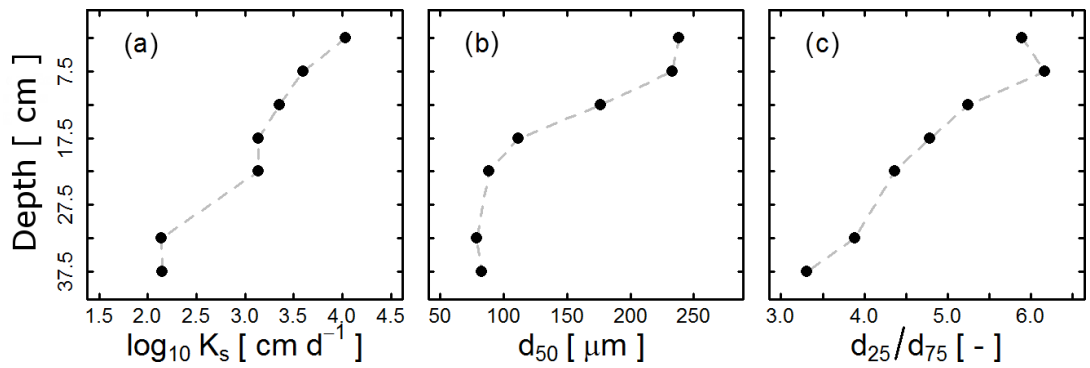

Figure 7. (a) Trends of key pore-system characteristics with depth: (a) near-exponential decrease in $K_{\mathrm{S}}$ with depth, (b) decrease in characteristic pore diameter with depth, expressed as the median pore diameter $d_{50}$ of the second modality, and (c) reduction of the width of the pore-size distribution with depth, expressed by $d_{75} / d_{25}$.

Table 2. PDI3-model parameter* values of the depth-averaged effective soil hydraulic properties.

\begin{tabular}{lccccccccccccc}
\hline $\begin{array}{l}\text { Depth } \\
(\mathrm{cm})\end{array}$ & $\begin{array}{c}\theta_{\mathrm{r}} \\
(-)\end{array}$ & $\begin{array}{c}\theta_{\mathrm{S}} \\
(-)\end{array}$ & $\begin{array}{c}\alpha_{1} \\
\left(\mathrm{~cm}^{-1}\right)\end{array}$ & $\begin{array}{c}n_{1} \\
(-)\end{array}$ & $\begin{array}{c}w_{1} \\
(-)\end{array}$ & $\begin{array}{r}\alpha_{2} \\
\left(\mathrm{~cm}^{1}\right)\end{array}$ & $\begin{array}{c}n_{2} \\
(-)\end{array}$ & $\begin{array}{c}w_{2} \\
(-)\end{array}$ & $\begin{array}{c}\alpha_{3} \\
\left(\mathrm{~cm}^{-1}\right)\end{array}$ & $\begin{array}{r}n_{3} \\
(-)\end{array}$ & $\begin{array}{r}\lg K_{\mathrm{s}} \\
\left(\mathrm{cm} \mathrm{day}^{-1}\right)\end{array}$ & $\begin{array}{c}\tau \\
(-)\end{array}$ & $\begin{array}{c}\lg \omega \\
(-)\end{array}$ \\
\hline 2.5 & 0.12 & 0.97 & 0.96 & 2.0 & 0.18 & 0.1 & 2.1 & 0.66 & 0.006 & 6.4 & 4.0 & 0.6 & -5.9 \\
7.5 & 0.09 & 0.97 & 0.26 & 1.8 & 0.50 & 0.07 & 2.1 & 0.30 & 0.006 & 6.2 & 3.6 & 0.6 & -4.2 \\
12.5 & 0.10 & 0.98 & 0.19 & 3.3 & 0.20 & 0.07 & 2.0 & 0.60 & 0.006 & 7.5 & 3.4 & 1 & -4.2 \\
17.5 & 0.06 & 0.97 & 0.18 & 1.4 & 0.42 & 0.05 & 2.9 & 0.37 & 0.006 & 4.9 & 3.1 & 1.0 & -5.9 \\
22.5 & 0.04 & 0.96 & 0.44 & 1.1 & 0.24 & 0.04 & 2.9 & 0.46 & 0.006 & 3.1 & 2.8 & 1.7 & -6.0 \\
32.5 & 0.09 & 0.97 & 0.04 & 3.4 & 0.55 & 0.02 & 1.7 & 0.25 & 0.005 & 5.3 & 2.1 & 0.2 & -5.6 \\
37.5 & 0.06 & 0.97 & 0.04 & 3.0 & 0.61 & 0.02 & 1.5 & 0.17 & 0.005 & 6.6 & 2.1 & 0.3 & -5.7 \\
\hline
\end{tabular}

* $\theta_{\mathrm{r}}$ : residual water content, $\theta_{\mathrm{s}}$ : saturated water content, $\alpha_{i}$ and $n_{i}$ : shape parameters of the three superimposed capillary bundles, respectively, $w_{i}$ : weighting coefficient of the capillary bundles, $K_{\mathrm{S}}$ : saturated hydraulic conductivity, $\omega$ : non-capillary conductivity, $\tau$ : tortuosity parameter. The common logarithm to the base 10 is denoted by $\lg$. The parameters of all individual samples can be found in the Supplement.

\section{Proposal of a pore-size classification for Sphagnum moss and peat}

The results of our study suggest a pore-size classification that is based on the three different pore domains characterized by the air-entry pressures (Eq. 3, Table 3). This classification relates the PSD to different physical components of moss and peat and hereby also directly links the SHP to pedogenesis. The resulting averaged air-entry pressures for the first, second, and third pore domains are given as $\mathrm{pF} 0,1$, and 2 , respectively, and in the following we give a detailed description of the pore water domains and the residual water (Fig. 8, Table 4). I-III are based on capillary water storage and IV is based on non-capillary (adsorptive) water storage.

The first domain (I) extends from saturation to a pressure head of approx. $-10 \mathrm{~cm}(\mathrm{pF}=1)$, which is marked by the mean $\bar{h}_{\mathrm{ae}, 2}$, corresponding to effective pore diameters of $>300 \mu \mathrm{m}$. At this point the HCCs of different depths converge in the sense that for $\mathrm{pF}>1$ the scatter is significantly reduced and the individual curves run in parallel with a range of approximately 1 order of magnitude (Fig. 5). This pressure head corresponds to a state where the highly heterogeneous inter-plant pores (living and slightly decayed Sphagnum) have drained (Fig. 1).
Table 3. Air-entry pressures of the three pore systems of the effective SHP for all sampling depths (left column) and arithmetic means to delimit the individual pore domains.

\begin{tabular}{lrrr}
\hline $\begin{array}{l}\text { Depth } \\
(\mathrm{cm})\end{array}$ & $\begin{array}{r}h_{\mathrm{ae}, 1} \\
(\mathrm{~cm})\end{array}$ & $\begin{array}{r}h_{\mathrm{ae}, 2} \\
(\mathrm{~cm})\end{array}$ & $\begin{array}{r}h_{\mathrm{ae}, 3} \\
(\mathrm{~cm})\end{array}$ \\
\hline 2.5 & -0.3 & -3.4 & -108 \\
7.5 & -1.2 & -4.9 & -107 \\
12.5 & -2.4 & -4.7 & -104 \\
17.5 & -1.7 & -9.3 & -96 \\
22.5 & -1.8 & -10.5 & -72 \\
32.5 & $-11.8^{*}$ & -31.8 & -117 \\
37.5 & $-10.8^{*}$ & -20.2 & -132 \\
\hline Mean & -1.5 & -8.0 & -105 \\
\hline SD & -0.7 & -3.2 & -17.1 \\
\hline
\end{tabular}

* As previously established, the depths 32.5 and $37.5 \mathrm{~cm}$ show no macro porosity and are excluded from calculating the mean and standard deviation for the average $\bar{h}_{\mathrm{ae}, 1}$ value. The mean $\bar{h}_{\mathrm{ae}, 2}$ value is calculated from the $h_{\mathrm{ae}, 2}$ values of the sampling depths $2.5-27.5 \mathrm{~cm}$, and the two $h_{\mathrm{ae}, 1}$ values at depths 32.5 and $37.5 \mathrm{~cm}$. The mean $\bar{h}_{\mathrm{ae}, 3}$ value is calculated based on all depths. 
Table 4. Overview of the proposed pore domain nomenclature with corresponding pressure head delimitations and effective pore diameters.

\begin{tabular}{|c|c|c|c|c|}
\hline Name of pore domain & $\begin{array}{l}\text { Pore } \\
\text { domain } \\
\text { number }\end{array}$ & $\begin{array}{l}\text { Effective } \\
\text { pore } \\
\text { diameter } \\
(\mu \mathrm{m})\end{array}$ & $\begin{array}{l}\text { Pressure } \\
\text { head } \\
(\mathrm{cm})\end{array}$ & $\begin{array}{l}\mathrm{pF} \\
(-)\end{array}$ \\
\hline Inter-plant pores & I & $>300$ & $>-10$ & 1 \\
\hline $\begin{array}{l}\text { Intra-plant and } \\
\text { outer-plant matrix }{ }^{1} \text { pores }\end{array}$ & II & 300 to 30 & -10 to -100 & $1-2$ \\
\hline $\begin{array}{l}\text { Inner-plant and } \\
\text { plant matrix }{ }^{1} \text { pores }\end{array}$ & III & 30 to 10 & -100 to -300 & $2-2.5$ \\
\hline $\begin{array}{l}\text { non-capillary, } \\
\text { cytoplasmic and } \\
\text { apoplastic water }\end{array}$ & IV & $\mathrm{n} / \mathrm{a}^{2}$ & $<-1000$ & $>\mathrm{pF} 3$ \\
\hline
\end{tabular}

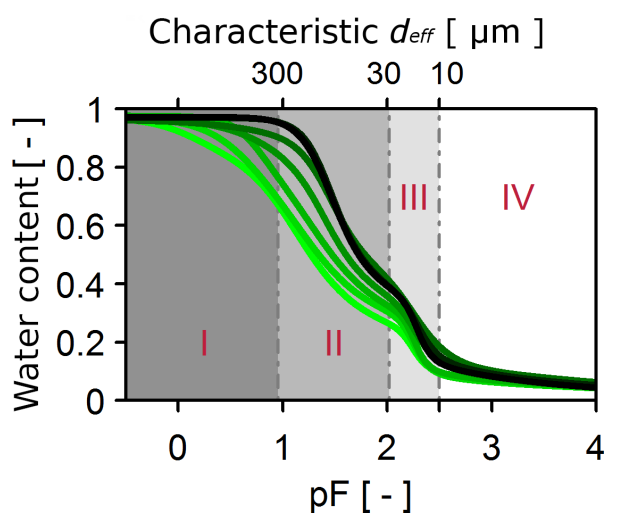

Figure 8. Four pore domains represented in the soil water retention curve. The Roman letters I-III denote different capillary water domains for which a detailed explanation is given in the text and values are presented in Table 4 . The region denoted by IV is non-capillary (residual) water.

The second domain (II) extends from $\mathrm{pF}=1$ to $\mathrm{pF}=2$, corresponding to effective pore diameters between 300 and $30 \mu \mathrm{m}$. It comprises the intra-plant pore space in the sampling depths 2.5 to $27.5 \mathrm{~cm}$ where macroscopic living and undecomposed moss fragments exist. At the remaining sampling depths decomposition is advanced, but the skeletal structures containing the hyaline cells remain (Fig. 1). Correspondingly the water in the second domain is stored here in the outer skeletal spaces of the peat (Rezanezhad et al., 2016).

Finally, the third pore domain (II) is represented by intact and decayed hyaline cells with effective pore radii of 30 to $10 \mu \mathrm{m}$. As shown in Fig. 1, the hyaline cells can still have intact cell membranes, but appear to decay more rapidly than the structures bearing them. In fact, the distances be- tween two structural elements (skeleton) making up the hyaline cells is, effectively, marginally larger than the hyaline cell opening.

Thus, in the absence of macropores, two size classes can be differentiated in decomposed Sphagnum peat; the outerplant matrix pores $>30 \mu \mathrm{m}$, and the inner-plant matrix pores with effective pore radii 30 to $10 \mu \mathrm{m}$ (Table 4 ). The abovementioned hyaline cells and their skeletal structures are drained by $\mathrm{pF}=2.5$, which is the pressure head where the fourth domain $(I V)$ starts. At these pressures of $\mathrm{pF}>2.5$, the water conductance can no longer be described by capillary flow theory.

In our analysis we assume that shrinkage does not affect our key findings. Shrinkage was observed to be around 5$8 \%$ on samples from the same depths and same bog, as referenced to the initial volume. Since the delimitations of our pore-size classification span orders of magnitude in pressure head and related effective pore radii, we believe that shrinkage will not have a considerable influence on the derived soil hydraulic properties for the small scale.

In line with these definitions, a pressure head delimitation of pore water into an active porosity (inter-and intra-plant and inter-plant matrix pore space) and an inactive porosity (inner-plant and inner-plant matrix) at a pressure head of $h=-100 \mathrm{~cm}$ is suggested. Finally, a word of caution with respect to generalizing our findings: Michaelis (2011) describes 286 species of Sphagnum, occurring globally; thus, our results might not be applicable to all species, since the phenology of decaying Sphagnum might be different between species. 


\section{Conclusions}

Based on measured data from transient evaporation experiments and an evaluation by inverse modelling using the Richards equation as a process model, we identified SHP for 28 samples from an acrotelm of an ombrotrophic, Sphagnum moss dominated bog. To parameterize the SHP, we compared six different models. The successful description of the observed data was possible by (a) considering three modalities representing the underlying PSD and (b) including the contribution of non-capillary water in the SHP models. Combined, this results in an encompassing parameterization across the full moisture range. The continuous information from fully parameterized models, available from the presented work, greatly extends the level of detail in comparison to previous works.

We averaged the SHP for each of the seven sampled depths and found, compared to insights from biological studies, that these mean hydraulic properties reflect the physiological nature of the pore-size domains in the living moss carpets of peat bogs. Larger heterogeneities in identified SHP between depth replicates could be shown for samples from the living moss; however, this effect reduced considerably with increasing depth and a concomitant reduction of PSDs from tri- to bi-modal. Both effects, the homogenization and reduction in modality, can be explained by pedogenic processes.

A unifying nomenclature to describe and report results from research on the vadose zone of ombrotrophic peatlands is proposed. With this, the pore spaces in Sphagnum moss and peat can be classified according to size ranges of the effective pore diameters. These size ranges are derived from an analysis of the shape of SHP and underlying PSDs from the uppermost $40 \mathrm{~cm}$ of the acrotelm. In living Sphagnum moss, the three pore spaces are thus proposed to be referred to as inter-, intra-, and inner-plant pore spaces, with effective pore diameters of $>300,300$ to 30 , and 30 to $10 \mu \mathrm{m}$, respectively. For deeper samples, the pedogenesis of the acrotelm has had a considerable impact on the shape of the SHP. First, the collapse of the inter-plant pores and their filling with smaller particles led to more homogeneous and gradually bimodal PSDs with increasing depth. Much of the hyaline cell structure and skeleton remains less affected by compaction and is resilient to decomposition. These remaining larger pores with effective pore diameters of $>300 \mu \mathrm{m}$ and fine pores of 30 to $10 \mu \mathrm{m}$ correspond more to the plant matrix than the fully visible plant and were thus described as outer-plant matrix pores and the inner-plant matrix, respectively.
Following these delimitations and with depth-continuous differentiation between the larger pores and inner-plant pores, we conclude that, based on this soil hydrological perspective, the water storage domain suggests a partitioning into active and inactive porosities when considering solute transport and is delimited at a pressure head of $h=-100 \mathrm{~cm}$. The proposed domain classification was inferred from a soil hydrological modelling approach and, with the discussion of the physiological meaning, we associate them with measurements and reflections in the seminal biological studies by Hayward and Clymo (1982), Lewis (1988), and van Breemen (1995).

Future research should include testing the Richards equation under various boundary conditions to verify that the identified SHP can be used for predictive purposes. Additionally, the research should be conducted to establish whether proxies such as bulk density, $\mathrm{C} / \mathrm{N}$ ratios, and/or vegetation structure can be used to predict SHP accurately. Lastly, scaling approaches are expected to help to describe in numerical simulations the gradual and continuous change in SHP with depth.

Code and data availability. Codes can be made available upon request. Measured data (pressure heads at two depths and evaporation rates) are available in the form of the HYDRUS 1-D input files in the online Supplement. 


\section{Appendix A: PDI model equations}

The WRC of the PDI model family (Peters, 2013, 2014; Iden and Durner, 2014) is given by the equation

$\theta(h)=\left(\theta_{\mathrm{s}}-\theta_{\mathrm{r}}\right) S_{\mathrm{c}}(h)+\theta_{\mathrm{r}} S_{\mathrm{nc}}(h)$

where $\theta(-)$ is volumetric water content, $h(\mathrm{~cm})$ is pressure head, and $S_{\mathrm{c}}(h)(-)$ and $S_{\mathrm{nc}}(h)(-)$ are the saturation functions for capillary and non-capillary water, respectively. $S_{\mathrm{c}}(h)(-)$ is defined as

$S_{\mathrm{c}}(h)=\frac{\Gamma(h)-\Gamma_{0}}{1-\Gamma_{0}}$

where $\Gamma_{0}=\Gamma\left(h_{0}\right), h_{0}(\mathrm{~cm})$ is the pressure head at oven dryness, and $\Gamma(h)$ is the multimodal van Genuchten saturation function (Durner, 1994)

$\Gamma(h)=\sum_{i=1}^{k} \Gamma_{i}(h)=\sum_{i=1}^{k} w_{i}\left[1+\left(-\alpha_{i} h\right)^{n_{i}}\right]^{-m_{i}}$

with shape parameters $\alpha_{i}\left(\mathrm{~cm}^{-1}\right)$ and $n_{i}$, the constraint $m_{i}=1-1 / n_{i}$, the number of modes or pore systems, $k(-)$, and weights $w_{i}$ which sum to unity. The non-capillary saturation function is given as

$S_{\mathrm{nc}}(h)=1+\frac{1}{x_{a}+x_{0}}\left\{x-x_{\mathrm{a}}+\ln \left[1+\exp \left(\frac{x_{a}-x}{b}\right)\right]\right\}$ where $x=\log _{10}(-h), x_{a}=\log _{10}\left(-h_{a}\right), x_{0}=\log _{10}\left(-h_{0}\right)$, and $h_{a}=1 / \alpha_{1}$. Parameter $b$ is a smoothing parameter for which empirical equations are given in Iden and Durner (2014). The HCC is defined as

$K(h)=(1-\omega) K_{\mathrm{s}} K_{\mathrm{rc}}\left(S_{\mathrm{c}}\right)+\omega K_{\mathrm{s}} K_{\mathrm{rnc}}\left(S_{\mathrm{nc}}\right)+K_{\mathrm{v}}(h)$

where $\omega(-)$ is the relative proportion of water flow in films and corners, $K_{\mathrm{rc}}(h)(-)$ is relative hydraulic conductivity caused by flow in completely filled capillaries, $K_{\text {rnc }}(h)(-$ ) is relative hydraulic conductivity caused by flow in films and corners (incompletely filled capillaries), and $K_{\mathrm{v}}(h)$ is the effective hydraulic conductivity for isothermal vapour diffusion. The equation for $K_{\mathrm{v}}(h)$ can be found in Saito et al. (2006) and the closed-form equations for the two liquid conductivities are (Peters, 2013, 2014)

$K_{\mathrm{rc}}\left(S_{\mathrm{c}}\right)=S_{\mathrm{c}}^{\tau}\left[1-\left(\frac{\sum_{i=1}^{k} w_{i} \alpha_{i}\left(1-\Gamma_{i}^{1 / m_{i}}\right)^{m_{i}}}{\sum_{i=1}^{k} w_{i} \alpha_{i}\left(1-\Gamma_{i, 0}^{1 / m_{i}}\right)^{m_{i}}}\right]^{m}\right]^{2}$

and

$K_{\mathrm{rnc}}\left(S_{\mathrm{nc}}\right)=\left(\frac{h_{0}}{h_{a}}\right)^{a\left(1-S_{\mathrm{nc}}\right)}$

where $\Gamma_{i, 0}=\Gamma_{i}\left(h_{0}\right)$ and $a=1.5$ is an empirical parameter for film flow (Tokunaga, 2009). 


\section{The Supplement related to this article is available online at https://doi.org/10.5194/hess-21-6185-2017- supplement.}

Author contributions. TW designed the study and experiments and carried them out. SI developed the model code and jointly performed the simulations with TW. TW prepared the manuscript with contributions from all co-authors. WD oversaw the formal analysis, acquired the funds, and provided all the necessary resources for this research.

Competing interests. The authors declare that they have no conflict of interest.

Acknowledgements. We wish to express our gratitude to the Niedersächsische Technische Hochschule for grant TD 2.1.4 Top-Down-Project GeoFluxes and for the research scholarship awarded to Tobias Karl David Weber by the German Academic Exchange Service. Thanks to Benedikt Scharnagl and Efstathios Diamantopolous for fruitful discussions, to H.-U. Kison of the Harz National Park for granting site access, as well as to our esteemed fellow geoecologists Daniela Reineke, Lennart Rolfes, and Matthias Spieckerman for their diligent work in the field and lab. For the images we wish to thank Reuven Simhayov for providing and Christina Smeaton for creating the scanning electron microscope image, and to Bent Johnsen for the drawing of Sphagnum magellanicum in Fig. 1 (@Department of Biology, University of Copenhagen). We additionally greatly thank Andy Baird and Donald Siegel for their constructive reviews and discussion which helped us to improve the manuscript, and Brian Berkowitz for the editorial work.

Edited by: Brian Berkowitz

Reviewed by: Andrew Baird and Donald Siegel

\section{References}

Assouline, S., Tessier, D., and Bruand, A.: A conceptual model of the soil water retention curve, Water Resour. Res., 34, 223-231, 1998.

Balyea, L. R.: Nonlinear Dynamics of Peatlands and Potential Feedbacks on the Climate System, in: Carbon Cycling in Northern Peatlands, Geophysical Monograph 184, Geophysical Monograph Series, edited by: Baird, A. J., Belyea, L. R., Comas, X., Reeve, A. S., and Slater, L. D., American Geophysical Union, Washington, D.C., 2009.

Baumann, K.: Entwicklung der Moorvegetation im Nationalpark Harz, in: Schriftenreihe aus dem Nationalpark Harz, Band 4, Nationalpark Harz, Wernigerode, 2009.

Blume, H.-P., Brümmer, G. W., Fleige, H., Horn, R., Kandeler, E., Kögel-Knabner, I., Kretzschmar, R., Stahr, K., and Wilke, B.-M.: Scheffer/Schachtschabel Soil Science, Springer, Berlin, Heidelberg, 618 pp., https://doi.org/10.1007/978-3-642-30942-7, 2016.
Boelter, D. H.: Physical Properties of Peat as related to degree of decomposition, Soil Sci Soc Am Proc, 33, 606-609, 1969.

Branham, J. E. and Strack, M.: Saturated hydraulic conductivity in Sphagnum-dominated peatlands: do microforms matter?, Hydrol. Process., 28, 4161-4387, https://doi.org/10.1002/hyp.10228 2014.

Broder, T. and Biester, H.: Hydrologic controls on DOC, As and $\mathrm{Pb}$ export from a polluted peatland - the importance of heavy rain events, antecedent moisture conditions and hydrological connectivity, Biogeosciences, 12, 4651-4664, https://doi.org/10.5194/bg-12-4651-2015, 2015.

Clymo, R. S.: The growth of Sphagnum: methods of measurement, J. Ecol., 58, 13-40, 1970.

Clymo, R. S.: The growth of Sphagnum: some effects of environment, J. Ecol., 61, 849-869, 1973.

Clymo, R. S.: A model of peat-bog growth. Production Ecology of some British Moors and Montane Grasslands, edited by: Heal, O. W., Perkins, D. F., and Brown, W. M., Springer, Berlin, 187-223, 1978.

Clymo, R. S.: The Limits to Peat Bog Growth, Philos. T. Roy. Soc. B, 303, 605-654, 1984.

Clymo, R. S. and Hayward, P. M.: Ecology of Sphagnum, in: Bryophyte Ecology, Chapman and Hall, London, UK, 229-289, 1982.

Dettmann, U. and Bechtold, M.: Deriving effective soil water retention characteristics from shallow water table fluctuations in peatlands, Vadose Zone J., 15, 1-13, https://doi.org/10.2136/vzj2016.04.0029, 2016.

Dimitrov, D. D., Grant, R. F., Lafleur, P. M., and Humphreys, E. R.: Modeling the effects of hydrology on ecosystem respiration at Mer Bleue bog, J. Geophys. Res., 115, G04043, https://doi.org/10.1029/2010JG001312, 2010.

Durner, W.: Hydraulic conductivity estimation for soils with heterogeneous pore structure, Water Resour. Res., 30, 211-223, 1994.

Durner, W. and Iden, S. C.: Extended multistep outflow method for the accurate determination of soil hydraulic properties near water saturation, Water Resour. Res., 47, W08526, https://doi.org/10.1029/2011WR010632, 2011.

Durner, W., Jansen, U., and Iden, S. C.: Effective hydraulic properties of layered soils at the lysimeter scale determined by inverse modelling, Eur. J. Soil Sci., 59, 114-124, https://doi.org/10.1111/j.1365-2389.2007.00972.x, 2008.

Frolking, S. and Roulet, N. T.: Holocene radiative forcing impact of northern peatland carbon accumulation and methane emissions, Global Change Biol., 13, 1079-1088, 2007.

Glaser, P. H., Chasar, L. I., Chanton, J. P., Morin, P., Rosenberry, D. O., Siegel, D. I., Ruud, O., and Reeve, A. S.: Surface deformations as indicators of deep ebullition fluxes in a large northern peatland, Global Biogeochem. Cy., 18, GB1003, https://doi.org/10.1029/2003GB002069, 2004.

Goetz, J. and Price, J. S.: Role of morphological structure and layering of Sphagnum and Tomenthypnum mosses on moss productivity and evaporation rates, Can. J. Soil Sci., 95, 109-124, https://doi.org/10.4141/CJSS-2014-092, 2015.

Hájek, T. and Beckett, R. P.: Effect of Water Content Components on Desiccation and Recovery in Sphagnum Mosses, Ann. Bot., 101, 165-173, https://doi.org/10.1093/aob/mcm287, 2008.

Hayward, P. M. and Clymo, R. S.: Profiles of Water Content and Pore Size in Sphagnum and Peat, and their Rela- 
tion to Peat Bog Ecology, P. Roy. Soc. B, 215, 299-325, https://doi.org/10.1098/rspb.1982.0044, 1982.

Hedwall, P.-O., Brunet, J., and Rydin, H.: Peatland plant communities under global change: negative feedback loops counteract shifts in species composition, Ecology, 98, 150-161, https://doi.org/10.1002/ecy.1627, 2017.

Hoffmann-Riem, H., van Genuchten, M. T., and Flühler, H.: A general model of the hydraulic conductivity of unsaturated soils, in: Proceedings of International Workshop, Characterization and Measurements of the Hydraulic Properties of Unsaturated Porous Media, edited by: van Genuchten, M. T., Leij, F. J., and Wu, L., University of California, Riverside, CA, 31-42, 1999.

Holden, J.: Piping and woody plants in peatlands: Cause or effect?, Water Resour. Res., 41, W06009, https://doi.org/10.1029/2004WR003909, 2005.

Iden, S. C. and Durner, W.: Comment on "Simple consistent models for water retention and hydraulic conductivity in the complete moisture range" by A. Peters, Water Resour. Res., 50, 1-5, https://doi.org/10.1002/2014WR015937, 2014.

Ingram, H. A. P.: Soil layers in mires: function and terminology, J. Soil Sci., 29, 224-227, 1978.

Jensen, U.: Die Moore des Hochharzes. Spezieller Teil, Niedersächsisches Landesverwaltungsamt, Hannover, Germany, 1990.

Johnson, L. C., Damman, A. W. H., and Malmer, N.: Sphagnum macrostructure as an indicator of decay and compaction in peat cores from an ombrotrophic south Swedish peat-bog, J. Ecol., 78, 633-647, 1990.

Jones, C. G., Lawton, J. H., and Shachak, M.: Organisms as ecosystem engineers, Oikos, 69, 373-386, 1994.

Jury, W. and Horton, R.: Soil Physics, 6th Edition John Wiley \& Sons, New York, p. 390, 2004.

Kettridge, N. and Binley, A.: Characterization of peat structure using X-ray computed tomography and its control on ebullition of biogenic gas bubbles, J. Geophys. Res., 116, G01024, https://doi.org/10.1029/2010JG001478, 2011.

Klute, A. and Dirksen, C.: Hydraulic conductivity and diffusivity: laboratory methods, in: Methods of Soil Analysis, Part 1. Physical and Mineralogical Methods, edited by: Klute, A., American Society of Agronomy, Inc., Madison, WI, 687-734, 1986.

Kuhry, P. and Vitt, D.: Fossil carbon/nitrogen ratios as a measure of peat decomposition, Ecology, 77, 271-275, 1996.

Lewis, A. M.: A test of the air-seeding hypothesis using Sphagnum hyalocysts, Plant Physiol., 87, 577-582, https://doi.org/10.1104/87.3.577, 1988.

Limpens, J., Berendse, F., Blodau, C., Canadell, J. G., Freeman, C., Holden, J., Roulet, N., Rydin, H., and Schaepman-Strub, G.: Peatlands and the carbon cycle: from local processes to global implications - a synthesis, Biogeosciences, 5, 1475-1491, https://doi.org/10.5194/bg-5-1475-2008, 2008.

McCarter, C. P. R. and Price, J. S.: Ecohydrology of Sphagnum moss hummocks: mechanisms of capitula water supply and simulated effects of evaporation, Ecohydrology, 7, 33-44, https://doi.org/10.1002/eco.1313, 2012.

McCarter, C. P. R. and Price, J. S.: The hydrology of the Boisdes-Bel peatland restoration: hydrophysical properties limiting connectivity between regenerated Sphagnum and remnant vacuum harvested peat deposit, Ecohydrology, 8, 173-187, https://doi.org/10.1002/eco.1498, 2014.
McCarter, C. P. R., Ketcheson, S., Weber, T. K. D., Whittington, P., Scarlett, S., and Price, J. S.: A modified technique for measuring unsaturated hydraulic conductivity in Sphagnum moss and peat, Soil Sci. Soc. Am. J., 81, 747-757, https://doi.org/10.2136/sssaj2017.01.0006, 2017.

Meiers, G. P., Barbour, S. L., Qualizza, C. V., and Dobchuk, B. S.: Evolution of the Hydraulic Conductivity of Reclamation Covers over Sodic/Saline Mining Overburden, J. Geotech. Geoenviron. Eng., 137, 968-976, https://doi.org/10.1061/(ASCE)GT.19435606.0000523, 2013.

Mezbahuddin, M., Grant, R. F., and Flanagan, L. B.: Modeling hydrological controls on variations in peat water content, water table depth, and surface energy exchange of a boreal western Canadian fen peatland, J. Geophys. Res.-Biogeo., 121, 2216-2242, https://doi.org/10.1002/2016JG003501, 2016.

Michaelis, D.: Die Sphagnum-Arten der Welt, Bibliotheca Botanica, 160, p. 408, 2011.

Morris, P. J., Baird, A. J., and Belyea, L. R.: Ecohydrological feedbacks in peatland development: a theoretical modelling study, J. Ecol., 99, 1190-1201, https://doi.org/10.1111/j.13652745.2011.01842.x, 2011.

Morris, P. J., Baird, A. J., and Belyea, L. R.: Bridging the gap between models and measurements of peat hydraulic conductivity, Water Resour. Res., 51, 5353-5364, https://doi.org/10.1002/2015WR017264, 2015.

Mualem, Y.: New model for redicting hydraulic conductivity of unsaturated porous, Water Resour. Res., 12, 513-522, 1976.

Mullen, K., Ardia, D., Gil, D., Windover, D., and Cline, J.: 'DEoptim': An R Package for Global Optimization by Differential Evolution, J. Stat. Softw., 40, 1-26, 2011.

Peters, A.: Simple consistent models for water retention and hydraulic conductivity in the complete moisture range, Water Resour. Res., 49, 6765-6780, https://doi.org/10.1002/wrcr.20548, 2013.

Peters, A.: Reply to comment by S. Iden and W. Durner on "Simple consistent models for water retention and hydraulic conductivity in the complete moisture range", Water Resour. Res., 50, 75357539, https://doi.org/10.1002/2014WR016107, 2014.

Peters, A. and Durner, W.: Simplified evaporation method for determining soil hydraulic properties, J. Hydrol., 356, 147-162, https://doi.org/10.1016/j.jhydrol.2008.04.016, 2008.

Peters, A., Durner, W., and Wessolek, G.: Consistent parameter constraints for soil hydraulic functions, Adv. Water Resour., 34, 1352-1365, https://doi.org/10.1016/j.advwatres.2011.07.006, 2011.

Price, J. S.: Role and character of seasonal peat soil deformation on the hydrology of undisturbed and cutover peatlands, Water Resour. Res., 39, 1241, https://doi.org/10.1029/2002WR001302, 2003.

Price, J. S. and Schlotzhauer, S. M.: Importance of shrinkage and compression in determining water storage changes in peat: the case of a mined peatland, Hydrol. Process., 13, 2591-2601, 1999.

Price, J. S. and Whittington, P. N.: Water flow in Sphagnum hummocks: Mesocosm 836 measurements and modelling, J. Hydrol., 381, 333-340, 2010.

Price, J. S., Heathwaite, A. L., and Baird, A. J.: Hydrological processes in abandoned and restored peatlands: An overview of management approaches, Wetlands Ecol. Manage., 11, 65-83, 2003. 
Price, J. S., Whittington, P. N., Elrick, D. E., Strack, M., Brunet, N., and Faux, E.: A method to determine unsaturated undecomposed Sphagnum moss, Soil Sci. Soc. Am. J., 72, 487-491, https://doi.org/10.2136/sssaj2007.0111N, 2008.

Price, J. S., Edwards, T. W. D., Yi, Y., and Whittington, P. N.: Physical and isotopic characterization of evaporation from Sphagnum moss, J. Hydrol., 369, 175-182, 2009.

Price, K. V., Storn, R. M., and Lampinen, J. A.: Differential Evolution - A Practical Approach to Global Optimization, SpringerVerlag, Berlin, Heidelberg, 2006.

Priesack, E. and Durner, W.: Closed-form expression for the multimodal unsaturated conductivity function, Vadose Zone J., 5, 121-124, https://doi.org/10.2136/vzj2005.0066, 2006.

Qi, G., Michel, J.-C., Boivin, P., and Charpentier, S.: A Laboratory Device for Continual Measurement of Water Retention and Shrink/Swell Properties during Drying/Wetting Cycles, Hortscience, 46, 1298-1302, 2011.

Quinton, W. L., Hayashi, M., and Carey, S. K.: Peat hydraulic conductivity in cold regions and its relation to pore size and geometry, 22, 2829-2837, https://doi.org/10.1002/hyp.7027, 2008.

Quinton, W. L., Elliot, T. R., Price, J. S., Rezanezhad, F., and Heck, R. J.: Measuring physical and hydraulic properties of peat from X-ray tomography, Geoderma, 153, 269-277, 2009.

Rezanezhad, F., Quinton, W. L., Price, J. S., Elrick, D., Elliot, T. R., and Heck, R. J.: Examining the effect of pore size distribution and shape on flow through unsaturated peat using computed tomography, Hydrol. Earth Syst. Sci., 13, 1993-2002, https://doi.org/10.5194/hess-13-1993-2009, 2009.

Rezanezhad, F., Quinton, W. L., Price, J. S., Elliot, T. R., Elrick, D., and Shook, K. R.: Influence of pore size and geometry on peat unsaturated hydraulic conductivity computed from 3D computed tomography image analysis, Hydrol. Process., 24, 2983-2994, 2010.

Rezanezhad, F., Price, J. S., Quinton, W. L., Lennartz, B., Milojevic, T., and Van Cappellen, P.: Structure of peat soils and implications for water storage, flow and solute transport: A review update for geochemists, Chem. Geol., 429, 75-84, 2016.

Rydin, H. and Jeglum, J. K.: The Biology of Peatlands, 2nd Edn., OUP, Oxford, p. 400, 2016.

Saito, H., Šimůnek, J., and Mohanty, B. P.: Numerical analysis of coupled water, vapor, and heat transport in the Vadose Zone, Vadose Zone J., 5, 784-800, https://doi.org/10.2136/vzj2006.0007, 2006.

Schlotzhauer, S. M. and Price, J. S.: Soil water flow dynamics in a managed cutover peat field, Quebec: Field and laboratory investigations, Water Resour. Res., 35, 3675-3683, 1999.

Schwärzel, K., Šimůnek, J., Stoffregen, H., Wessolek, G., and van Genuchten, M. T.: Estimation of the unsaturated hydraulic conductivity of peat soils: Laboratory versus field data, Vadose Zone J., 5, 628-640, 2006.

Sherwood, J. H., Kettridge, N., Thompson, D. K., Morris, P. J., Silins, U., and Waddington, J. M.: Effect of drainage and wildfire on peat hydrophysical properties, Hydrol. Process., 27, 18661874, https://doi.org/10.1002/hyp.9820, 2013.

Šimůnek, J., van Genuchten, M. T., and Miroslav, Š.: Recent Developments and Applications of the HYDRUS Computer Software Packages, Vadose Zone J., 15, https://doi.org/10.2136/vzj2016.04.0033, 2016.
Sulman, B. N., Desai, A. R., Schroeder, N. M., Ricciuto, D., Barr, A., Richardson, A. D., Flanagan, L. B., Lafleur, P. M., Tian, H., Chen, G., Grant, R. F., Poulter, B., Verbeeck, H., Ciais, P., Ringeval, B., Baker, I. T., Schaefer, K., Luo, Y., and Weng, E.: Impact of hydrological variations on modeling of peatland $\mathrm{CO}_{2}$ fluxes: Results from the North American Carbon Program site synthesis, J. Geophys. Res., 117, G01031, https://doi.org/10.1029/2011JG001862, 2012.

Tokunaga, T. K.: Hydraulic properties of adsorbed water films in unsaturated porous media, Water Resour. Res., 45, W06415, https://doi.org/10.1029/2009WR007734, 2009.

Valat, B., Jouany, C., and Rivere, L. M.: Characterization of the wetting and properties of air-dried peats and composts, Soil Sci., 152, 100-107, 1991.

van Breemen, N.: How Sphagnum bogs down other plants, Tree, 10, 270-275, 1995.

van Genuchten, M. T.: Closed-form equation for predicting the hydraulic conductivity of unsaturated soils, Soil Sci. Soc. Am. J., 44, 892-898, 1980.

Vereecken, H., Kasteel, R., Vanderborght, J., and Harter, J.: Upscaling Hydraulic Properties and Soil Water Flow Processes in Heterogeneous Soils: A Review, Vadose Zone J., 6, 1-28, https://doi.org/10.2136/vzj2006.0055, 2007.

Weber, T. K. D., Iden, S. C., and Durner, W.: Unsaturated hydraulic properties of Sphagnum moss and peat reveal trimodal pore-size distributions, Water Resour. Res., 53, 415-434, https://doi.org/10.1002/2016WR019707, 2017a.

Weber, T. K. D., Gerling, L., Reineke, S., Weber, S., Durner, W., and Iden, S. C.: Robust inverse modeling of net ecosystem exchange in a mountainous peatland: influence of distributional assumptions on estimated parameters and total carbon fluxes, J. Adv. Model. Earth Syst., in review, 2017b.

Weller, U., Ippisch, O., Köhne, M., and Vogel, H.-J.: Direct measurement of unsaturated conductivity including hydraulic nonequilibrium and hysteresis, Vadose Zone J., 10, 654-661, https://doi.org/10.2136/vzj2010.0074, 2011.

Wendroth, O., Ehlers, W., Hopmans, J. W., Kage, H., Halbertsma, J., and Wösten, J. H. M.: Reevaluation of the Evaporation Method for Determining Hydraulic Functions in Unsaturated Soils, Soil Sci. Soc. Am. J., 57, 1436-1443, https://doi.org/10.2136/sssaj1993.03615995005700060007x, 1993.

Wu, Y. and Blodau, C.: PEATBOG: a biogeochemical model for analyzing coupled carbon and nitrogen dynamics in northern peatlands, Geosci. Model Dev., 6, 1173-1207, https://doi.org/10.5194/gmd-6-1173-2013, 2013.

Ye, M., Meyer, P. D., and Neuman, S. P.: On model selection criteria in multimodel analysis, Water Resour. Res., 44, W03428, https://doi.org/10.1029/2008WR006803, 2008.

Zurmühl, T. and Durner, W.: Determination of $\mathrm{Pa}-$ rameters for Bimodal Hydraulic Functions by Inverse Modelling, Soil Sci. Soc. Am. J., 62, 874-880, https://doi.org/10.2136/sssaj1998.03615995006200040004x, 1998. 